\title{
A new future for the sea? A take on the risks associated with offshore wind farming
}

\author{
Marcus Lange, Andreas Kannen, Kira Gee \\ GKSS Research Center, Geesthacht, Germany
}

Global change is currently leading to a fundamental re-configuration of marine space. In the North Sea, climate change is one of the drivers that have resulted in a large proportion of North Sea space to be set aside for offshore wind farming (BMU 2007, BMWi 2008, Kannen \& Burkhard 2009, Gee (in print)). Whilst there are risks associated with not pursuing the offshore wind option, the large-scale expansion of offshore wind farming itself carries a different set of risks. Some of these risks are spatial in nature, increasing pressure of use on a space that is already heavily used. Other risks are economic, ecological and social in nature, manifesting themselves at different scales in the marine environment and further afield on the mainland.

Risk is a construct and a relative concept, meaning that risk perception is contingent in space and time. There is a large body of literature linking risk perception to change and uncertainty, the acceptance of new technologies and how to deal with systemic risk (e.g. Renn et al. 2007, Zwick et al. 2008). In this paper, we start from the premise that the classification of something as a risk requires the existence of something else that is 'at risk', an object or entity that is valued and could be considered threatened by new developments. This 'something' may be a personal and deeply held conviction or principle, but may also be the values assigned to particular elements of the environment and space. In the case of risks perceived in the context of offshore wind farming, a central question is thus what environmental values might be threatened by the large-scale expansion of offshore wind farms and whether this can be compensated for by appropriate management.

Using the West coast of Schleswig-Holstein as a case study, this paper discusses three selected constructs of environmental risk posed by offshore wind farm development The first is the construction of 'objective' ecological risk based on the interpretation of modelling data for selected bird species (Burkhard et al. 2010, Mendel et al. 2010). The second draws on survey results from the West coast of Schleswig-Holstein and focuses on risk perception of local coastal residents (Gee 2010). The third is the construction of risk by other sea users potentially affected by offshore wind farm development, where space is the value most at risk.

We then place these different perceptions of threat into the context of the current spatial planning framework used to guide offshore wind farm development in the German North Sea. We find that zoning is limited in the kinds of risks it can reduce. For comprehensive risk management in the context of offshore wind farming, more must be done to discuss the more fundamental values associated with the sea as a space since these are instrumental drivers of local perceptions of risk.

\section{References}

Bundesministerium für Umwelt (BMU) (2007), in Zusammenarbeit mit der Stiftung der deutschen Wirtschaft zur Nutzung und Erforschung der Windenergie auf See: Entwicklung der Offshore-Windenergienutzung in Deutschland. Broschüre, 29 S., Januar 2007.

Bundesministerium für Wirtschaft und Arbeit (BMWi) (2008): Schlaglichter der Wirtschaftspolitik, Monatsbericht 04/2008. www.bmwi.de 
Burkhard, B., Opitz, S., Lenhart, H., Ahrendt, K., Garthe, S., Mendel, B., Nerge, P. \& W. Windhorst (2010): Modellbasierte Bewertung der Auswirkungen von OffshoreWindkraftanlagen auf die ökologische Integrität der Nordsee. Coastline Report, forthcoming.

Kannen, A., Burkhard, B. (2009): Integrated Assessment of Coastal and Marine Changes Using the Example of Offshore Wind Farms: the Coastal Futures Approach. - GAIA 18/3, 229-238.

Gee, K. (2010) Offshore wind power development as affected by seascape values on the German North Sea coast. Land Use Policy 27, 185-194

Gee, K. (in print) Landschaftswandel und Wahrnehmung -- Das Beispiel Offshore-Windkraft. ZELTForum Band 5, Geographisches Institut der Universität Göttingen.

Mendel, B. \& S. Garthe (2010): Kumulative Auswirkungen von Offshore-Windkraftnutzung und Schiffsverkehr am Beispiel der Seetaucher in der Deutschen Bucht. Coastline Report, forthcoming.

Renn, O., Schweizer, P.-J., Dreyer, M. \& A. Klinke (2007): Risiko - Über den gesellschaftlichen Umgang mit Unsicherheiten. München, $271 \mathrm{~S}$.

Zwick, M.-M. \& O. Renn (2008): Risikokonzepte jenseits von Eintrittswahrscheinlichkeit und Schadenserwartung. In: Felgentreff, C. \& T. Glade (Hg.): Naturrisiken und Sozialkatastrophen. Berlin, Heidelberg, S. 77-97. 